\author{
A. Entomology \\ ISSN: 1687-8809 \\ www.eajbs.eg.net
}

\title{
Suppression of white mango scale, Aulacaspis tubercularis (Hemiptera: Diaspididae) on mango trees in El-Beheira Governorate, Egypt.
}

\author{
Abo-Shanab, A.S.H. \\ Central Agricultural Laboratory of Pesticides, Agricultural Research \\ Center,Sabahia, Alexandria
}

\section{ABSTRACT}

White mango scale, Aulacaspis tubercularis Newstead (Hemiptera: Diaspididae) is a serious pest on mango (Mangifera spp.), (Sapindales: Anacardiaceae) which became recently a troublesome pest in all mango orchards in Egypt. It causes fatal damage especially to late cultivars by sucking leaves which turn pale-green or yellow and ultimately die or fruit causing conspicuous pink blemishes around insect feeding sites resulting in external lesions rendering it unmarketable for export. Seasonal abundance was estimated throughout 2 successive years (2008 and 2009) and showed that the white mango scale (A. tubercularis) had four peaks for its population density during the two studied years, (April, August, October and December, 2008) and (March, July, September and December, 2009). Study of weather factors, [daily mean temperature $\left({ }^{\circ} \mathrm{C}\right)$, relative humidity $(\%)$, dew point $\left({ }^{\circ} \mathrm{C}\right)$ and wind speed $(\mathrm{Km} / \mathrm{h})]$ effects on A.tubercularis population density illustrated that there was significant positive relationship between (daily mean temperature and relative humidity) and counted population density, but there was a significant negative relationship between (wind speed and dew point) and counted population density. Two successive field experiments for eight weeks during early spring $(2009-2010)$ aimed to test some summer/light mineral oils, (super masrona ${ }^{\circledR}$, CAPL $2^{\circledR}$ and Diver ${ }^{\circledR}$ ) against $A$. tubercularis on mango trees. The tested mineral oils were effective by the following descending order : Diver $>$ CAPL2 ${ }^{\circledR}>$ super masrona ${ }^{\circledR}$ without significant differences between diver and CAPL2 and significant differences with super masrona, with the same effective trend and same statistical means, during the two seasonal experiments. The study recorded a little numbers of natural enemies (Parasitoids (Aphytis mytilaspidis_(Le Baron) and Encarsia citrina (Craw) (Hymenoptera: Aphelinidae)), and predators (Chilocorus bipustulatus (L.) and Scymnus syriacus Marseul (Coleoptera: Coccinellidae)). It may be killed by previous bad history of chemical insecticides usage in this area.

Keywords: white mango scale, Aulacaspis tubercularis , mango trees, Egypt.

\section{INTRODUCTION}

Aulacaspis tubercularis Newstead (Hemiptera : Diaspididae) (White mango scale insect) injures mangoes by feeding on the plant sap through leaves, branches and fruits, causing defoliation, drying up of young twigs, poor blossoming and so affecting the commercial value of fruits and their export potential especially to late cultivars where it causes conspicuous pink blemishes around the feeding sites of the scales. In nurseries, severe early stage infestation retards growth. Young trees are particularly vulnerable to excessive leaf loss and death of twigs, during hot dry weather. The heavily infested premature fruits dropping and the mature fruits became small in size with lacking of juice. A. tubercularis is a tropical species that may have

Workshop of Scale Insects and their role in agricultural development in Egypt. Held in Agricultural Research Center, Plant Protection Research Institute, Scale Insects Division (2012) 
originated in Asia. It has been recorded mainly from hosts belonging to four plant families : Palmae, Lauraceae, Rutaceae, Anacardiaceae, particularly on mangoes and cinnamon (Borchsenius, 1966).

Its population densities were recorded on mangoes in few parts of the world (Annecke, 1963; Almeida, 1972 and Labuschange et al., 1995). It has been spread by the transport of infested plant material and is now widespread in many mangogrowing countries. It presents as a significant pest problems on mangoes in South Africa (Colyn and Schaffer, 1993; Joubert et al. 2000a), in Australia, East and West Africa, North and South America and the Caribbean Islands (Peña et al., 1997). It has not been recorded from most of the tropical Pacific islands. (Tao, 1999; Porcelli, 1990; Longo et al., 1995; International Institute of Entomology (IIE), 1993 and Danzig, and Pellizzari, 1998). This insect became an economic pest all over Egypt, after it was restricted in Minia Governorate under quarantine regulations then crept to Beni-Suif Governorate, so population fluctuations and role of its natural enemies in regulating its abundance have not wide studied till now in Egypt, (Morsi, et al. 2002). The role of white mango scale insect natural enemies in regulating its abundance was discussed by some authors (Quednau, 1964; Viljoen, 1986; Schoeman, 1987; Labuschagne, 1993; Labuschagne and Pasques, 1994; Labuschagne and Beer, 1995; Labuschagne et al., 1996; Daneel and Dreyer, 1997 and 1998 and Joupert et al., $2000 \mathrm{~b}$ ).

Encarsia sp. (Hymenoptera: Aphelinidae) was recorded parasitizing $A$. tubercularis on mangoes in South Africa, where parasitism of female scales averaged 17.7\% (Schoeman, 1987). Viljoen (1986), discussed the natural enemies of mango scale present in South Africa. Van Halteren (1970), reported that parasitism by hymenopterous parasitoids was common on mangoes in Ghana, and reported attacks by an unnamed dipterous parasite. The coccinellid predators Rhyzobius lophanthae Blaisdell and Chilocorus nigrita (Fabricius) (Coleoptera: Coccinellidae) are common in South Africa, where they have been introduced, but are generally not sufficient in themselves to keep scale insect populations below economically damaging levels.

The present work carried out during a field study which conducted in private mango orchard in El-Gedia Village, Rasheed district, El-Beheira Governorate, where it aimed to study the seasonal abundance and population dynamics of A.tubercularis, survey of its natural enemies, (parasitoids and predators) on mango trees and efficiency of some summer mineral oils on insect and its natural enemies mortality.

\section{MATERIALS AND METHODS}

\section{Tested scale insect}

It considers an economic threat to mango trees, infested areas of mango leaves turn pale-green or yellow and ultimately die. Infested mango fruits have pink blemishes around feeding sites. White mango scale insects, A. tubercularis

\section{Seasonal Abundance and population fluctuations of the mango scale insect.}

The population density and seasonal abundance of $A$. tubercularis were carried out for 2 years (February, 2008 till January, 2010) in private mango orchard in El-Gedia Village, Rasheed district, El-Beheira Governorate. The orchard area under study was one Feddan, cultivated with the mango trees (since 1993) Mangifera indica L., heavily infested with the mango scale insect. From each corner of the area five trees were chosen in the same age and similar in size, shape and height. It was not exposed to any insecticidal treatment during the two years prior except our studied mineral oils treatments. 
Thirty leaves and five small branches ( $15 \mathrm{~cm}$ long) were picked out every two weeks (half-monthly) at random to represent the different sides/directions of each tree. Leaves and branches were put in cloth bags and transported directly to the laboratory of Scale Insects and Mealybugs Division, Plant Protection Institute, Agricultural Research Station, Alexandria, ARC, Ministry of Agric., Egypt, for classifying the detected species (white mango scale insect) using a stereoscopic binocular microscope. The upper and lower surfaces of the leaves and all the branches were examined. All tested scale insect were counted and recorded.

\section{Effect of weather factors}

Weather factors of daily mean temperature $\left({ }^{\circ} \mathrm{C}\right)$, relative humidity $(\%)$, dew point $\left({ }^{\circ} \mathrm{C}\right)$ and wind speed $(\mathrm{Km} / \mathrm{h})$, were studied to determine their effects on the population density of A. tubercularis. Monthly means records of these weather factors in El-Beheira Governorate were obtained from the general authority for Meteorology at Kobri El-Kobba, Cairo, corresponding to the precise period of sampling dates. Simple correlation (r) and partial regression (b) values were calculated to obtain information about the relationship between the mean number of individuals/tree and the mean records of the four tested weather factors. In an effort to estimate the distribution and population densities of the tested scale insect, obtained results were statistically analyzed according to (Snedecor, 1970).

\section{Insecticides studied}

Two field experiments were carried out in early spring of 2009 and 2010 in a neighboring private mango orchard trees (1 Fed.) (during fruiting stage) to evaluate the efficacy of three mineral oils with different purification percentages [Super Masrona oil ${ }^{\circledR} 95 \%$, CAPL2 oil ${ }^{\circledR} 96.62 \%$ and Diver oil ${ }^{\circledR} 97 \%$, against the armored scale insect [white mango scale, A. tubercularis Mango trees were 18 years old and have similar uniformity in shape and size. Experiment was designed as a complete randomized block (CRBD). Spraying was accomplished by means of a conventional knapsack motor sprayer (600 liter) at the rate of spray/feddan, at mean rate of 20 liters per tree to ensure complete coverage of all parts of the tree. Three treatments as well as the untreated check were replicated four times with five trees per replicate (with row of mango trees as a barrier in between) and randomly distributed over 100 trees. Thirty leaves were picked out randomly from all the four cardinal directions of the inspected trees in each replicate for laboratory counts, pre- spraying and four periodic intervals post spraying (two, four, six and eight weeks) according to Egyptian Agricultural Ministry scale insect pest control test guide. Picked samples were put in labeled cloth bags and transferred immediately to the laboratory. Living individuals (adults and immatures) were classified and counted on both surfaces of the leaves using a stereoscopic binocular microscope

The reduction of the inspection of insect numbers was expressed as reduction percentages which have been calculated according to (Stafford and Summers, 1963). Statistical analysis of variance and LSD value for comparing the mean effects of each treatment were adopted according to (Snedecor, 1970). The tested compounds and their type of treatments, rate of application, type of formulation and source of them are shown in Table (1).

Table 1: Type of treatments, rate of applications and the sources of it.

\begin{tabular}{|c|c|c|}
\hline Compounds & Rate $\%$ & Source (Company) \\
\hline CAPL2 oil $^{\mathbb{B}} 96.62 \%$ E.C & \multirow{3}{*}{1.5} & Central Agricultural Pesticides Laboratory (CAPL) \\
\hline Super Masrona oil ${ }^{\mathbb{R}} 95 \%$ E.C & & Misr Petrolium Co. \\
\hline Diver oil $^{\mathbb{B}} 97 \%$ E.C & & El-Helb pesticides and Chemical Co. \\
\hline
\end{tabular}




\section{RESULTS AND DISCUSSION}

\section{Seasonal abundance and population fluctuations of the mango scale insect:}

The seasonal abundance of the mango scale insect was estimated throughout 2 years (2008 and 2009) by direct counting on 30 leaves of mango from the beginning of February 2008 to January 2010. Data obtained (Fig., 1) showed that the population changes of the mango scale insect (A. tubercularis) where it had four peaks for its population during the two studied years, (April, August, October and December, 2008) and (March, July,

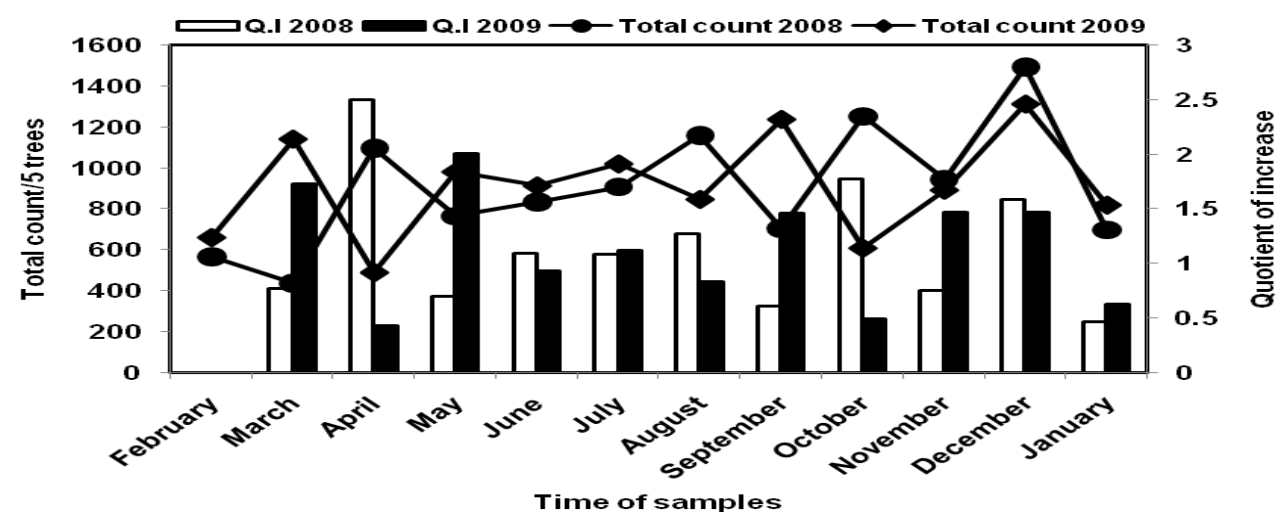

Fig. 1: Monthly variations in population count of Aulacaspis tubercularis infesting mango trees during 2008 and 2009.

September and December, 2009) where recorded total numbers of all stages of the mango scale insect per 30 leaves were 1095, 1158, 1252 and 1493 for the first year (2008) respectively, and 1140, 1019, 1446 and 1311, for the second year (2009), respectively. The data in Fig. (1) revealed also that the highest population density of collected individuals occurred by the end of autumn season and comprised 1493 and 1311 individuals/5 trees, which represented $16.02 \%$ and $16.29 \%$ of total counted individuals in the first and second year, respectively. The lowest population density was observed in the beginning of spring season during the two studies years where it recorded total count/5 trees 438 and 489 which represented $4.70 \%$ and $6.07 \%$ of total counted individual's in the first and second year, respectively. That is agree with Labushagne et al. (1996) research results which carried out in South Africa where he mentioned that population peak at Kaapmuiden, with a highest mean temperature occurred in August, much earlier than at Nelspruit, where it occurred in November.

\section{Effect of weather factors:}

The weather factors, daily mean temperature $\left({ }^{\circ} \mathrm{C}\right)$, relative humidity $(\%)$, dew point $\left({ }^{\circ} \mathrm{C}\right)$ and wind speed $(\mathrm{Km} / \mathrm{h})$ were studied with the monthly total counts of A.tubercularis on Mangifera spp. during the studied period. The results showed that there were significant positive relationship between (daily mean temperature and relative humidity) and recorded population density of A.tubercularis, and a significant negative relationship between (wind speed and dew point) and recorded population density of A.tubercularis, that is may due to transference of insect crawlers and early nymphal instars by the wind to another plants and/or places.

\section{Effect of tested Insecticides:}

Two large scale experiment were conducted during two fruiting seasons (early spring of 2009 and 2010) to evaluate the efficacy of three summer/light mineral oils [Super Masrona oil ${ }^{\circledR} 95 \%$, CAPL2 oil ${ }^{\circledR} 96.62 \%$ and Diver oil ${ }^{\circledR}$ 
97\%], against A.tubercularis infested Mango trees. Fig. (2) data indicated that, the summer oil, "Diver" was the most effective one during the two experiments (2009 and 2010) against $A$. tubercularis on mango trees followed by "CAPL2" and "super masrona" recorded the least effect among the tested insecticides through the experiments. There was no significant difference between reduction effect of Diver oil and CAPL2 oil, but there was significant difference between reduction effect of super masrona and the other two tested mineral oils. The tested mineral oils caused mean reduction effects $(90.15 \%),(93.55 \%)$ and $(95.43 \%)$ with check reduction effect (7.75\%) during the first experiment (2009) for super masrona, CAPL2 and Diver oils, respectively.

Data in Fig.(2) showed also that the mineral oil diver caused progressive reduction effect through the tested period up to the sixth week then its reduction effect decreased through the eighth week where it caused reduction effect (91.3\%), (97.2\%), $(97.6 \%)$ and $(95.6 \%)$ after 2, 4, 6 and 8 weeks. CAPL2 caused progressive reduction effect $(84.9 \%),(92.6 \%),(96.7 \%)$ and $(100 \%)$ after $2,4,6$ and 8 weeks from insecticides application but super masrona caused Imponderable reduction effect during the tested period $(89.2 \%),(84.5 \%),(95.1 \%)$ and $(91.8 \%)$ as well as the check on which had reduction effect $(6.3 \%),(11.6 \%),(4.7 \%)$ and $(8.4 \%)$ after 2, 4, 6 and 8 weeks from insecticides application. The second experiment data showed same effective trend for the tested insecticides with the same statistical means, where they caused mean reduction effect $(92.04 \%),(95.07 \%),(97.68 \%)$ and $(6.36 \%)$ for super masrona oil, CAPL2 oil, Diver oil and check treatments. All treatments showed imponderable reduction effect during the tested period 8 weeks Fig. (2).Using chemicals insecticides is hazardous, expensive, and often causes other problems such as natural enemies killing. So that this study aimed to test some summer/light mineral oils to illustrate that it cause good reduction percentages effect against the tested armored white mango scale insect infested mango trees with avoiding the abovementioned problems.

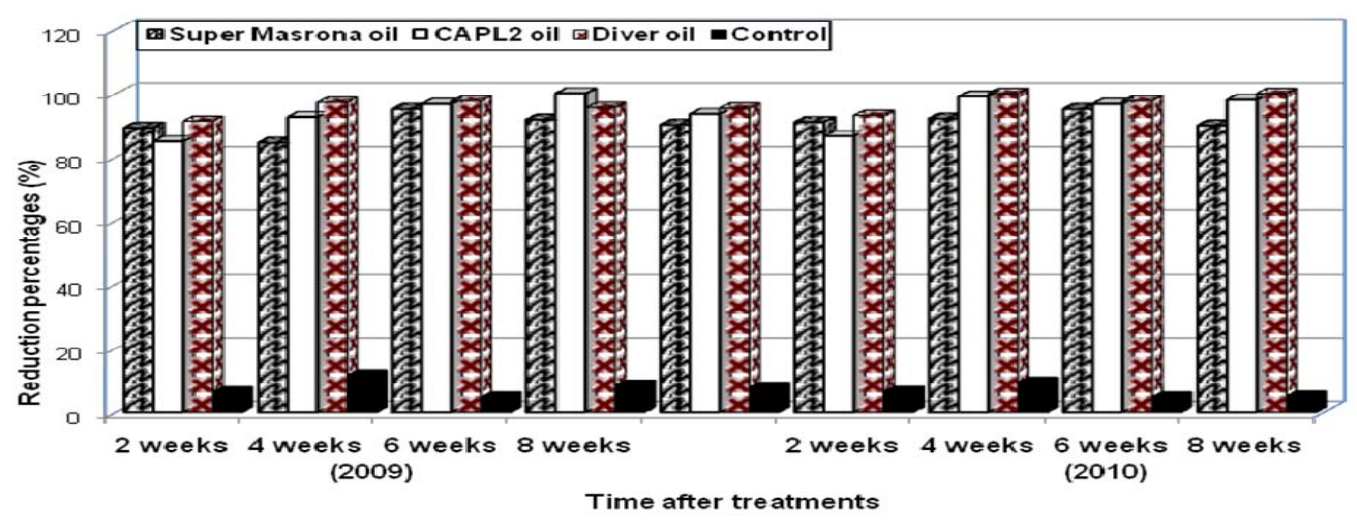

Fig. 2: Effect of tested materials on Aulacaspis tubercularis infested Mangifera spp. after time intervals of spraying at Rasheed district, El-Beheira Governorate.

These results are agreement with the recently an interesting extension of the use of mineral oils against homopterous insects is encouraged. Mineral oils are valuable insecticide materials because they have little residual toxicity for beneficial insects as mentioned by (Moursi et al., 1991; Abo-Shanab, 2005; Helmy et al., 2006 and ElHalawany et al., 1987). Potenza et al. (1993) described field studies of a range of insecticide and mineral oil combinations against $A$. tubercularis in mango orchards in Brazil. Certain insecticides are not recommended for use against mango scale, as 
marked increases in the pest population can result due to elimination of natural enemies (Viljoen and De Villiers, 1987).

Considering the probable occurring side effects of tested mineral oils on (nontarget) natural enemies (parasitoids and predators) of A. tubercularis on mango trees, we could not record significant numbers of them unless a little numbers of parasitoids Aphytis mytilaspidis_(Le Baron) and Encarsia citrina (Craw) (Hymenoptera: Aphelinidae) and predators Chilocorus bipustulatus (L.) and Scymnus syriacus Marseul (Coleoptera: Coccinellidae).

\section{REFERENCES}

Abo-Shanab, A.S. (2005): Efficacy of some IGR/insecticides, $\mathrm{Kz}$ mineral oil and binary mixtures on mortality and enzyme activity of Egyptian mealy bug Icerya aegyptiaca (Douglas) attacked Guava trees in Alexandria Governorate. J. Pest Cont. and Environ. Sci., 13(1): 73-85.

Almeida, D.M. (1972): Pests of mango (pragas da mangueira). Gazeta do Agricultor, $24: 2-5$

Annecke, D.P. (1963): Observation on some citrus pests in Mozambique and Southern Rhodesia.J. Ent. Soc. S. Afr., 26 (1):194-225.

Borchsenius, N.S. (1966): A catalogue of the armored scale insects (Diaspididea) of the world. (In Russian.) Nauka, Moscow, Leningrad, Russia, 449 pp.

Colyn, J. and Schaffer, B. (1993): The South African mango industry. Fourth International Mango Symposium, Miami, Florida, USA, 5-10 July 1992. Acta Horticulturae, 341: 60-68.

Daneel, M.S. and Dreyer, S. (1997): Further studies on the establishment Aphytis sp. and Cybocephalus binotatus in mango orchards for the control of the mango scale. Yearbook- South African - Mango Growers' Association, 17: 144-146.

Daneel, M.S. and Dreyer, S. (1998): Biological control of mango scale, Aulacaspis tubercularis, in South Africa. Yearbook- South African-Mango Growers' Association, 18: 52-55.

Danzig, E.M. and Pellizzari, G. (1998): Diaspididae. In: F. Kozár (ed.), Catalogue of Palaearctic Coccoidea. Hungarian Academy of Sciences. Akaprint Nyomdaipari Kft., Budapest, Hungary, 172-370.

El-Halawany, M.E.; Metwally, A.M. and Nassar, M.E. (1987): Activity of Albolium on the citrus brown mite biology and the sensitivity of different mite species to certain chemicals. Agric. Res. Rev., 65(1): 37-42.

Helmy, E. I.; Kwaiz, F. A. and Radwan, S. G. (2006): Mineral oils as safe alternative pesticides against Russellaspis (=Asterolecanium) pustulans (Cockerell) (Hemiptera: Coccoidea: Asterolecaniidae) on apple at El- Nobariya district, Egypt. Egypt. J. Appl. Sci., 21 (10B): 786 - 793.

International Institute of Entomology (1993): Distribution Maps of Pests. Series A, No. 540. CAB International, Wallingford, UK., 2 pp.

Joubert, P.H.; Daneel, M.S.; Grove, T.; and Pichakum, A. (2000 a): Progress towards integrated pest management (IPM) on mangoes in South Africa. Acta Horticulture No. 509: 811-817.

Joubert, P.H.; Daneel, M.S.; Grove, T.; Subhadrabandhu, S. and Pichakum, A. (2000 b): Progress towards integrated pest management (IPM) on mangoes in South Africa. Proceedings of the Sixth International Symposium on Mango, Pattaya City, Thailand, 6-9 April, 1999, Volume 2. Acta Horticulture, 509: 811-817. 
Labuschange, T.I.; Van-Hamburg, H. and Froneman, I.J. (1995) : Population dynamics of the mango scale, Aulacaspis tubercularis (Newstead), (Coccoidea: Diaspididae), in South Africa. Israel J. Entomol., 29: 207 - 217.

Labuschange, T. I. and Pasques, B. P. (1994): Imported parasites of the mango scale, Aulacaspis tubercularis, and the effect of Fenthion on the mango parasitoid, Aspidiotiphagus citrinus. Yearbook-South African-Mango Growers' Association, 14: 75 - 77.

Labuschange, T.I. (1993): Progress with integrated control of the mango scale, Aulacaspis tubercularis Newstead.Yearbook- South African - Mango Growers' Association, 13: 134-135.

Labuschange, T.I. and de Beer, M.S. (1995): First successful import of parasitoids of mango scale (Aulacaspis tubercularis Newstead) to South Africa. YearbookSouth African - Mango Growers' Association, 15: 106-108.

Labuschange, T.I.; Daneel, M.S. and De Beer, M.S. (1996): Establishment of Aphytis sp. (Hymenoptera: Aphelinidae) and Cybocephalus binotatus Grouvelle (Coleoptera: Nitidulidae) in mango orchards in South Africa for control of the mango scale, Aulacaspis tubercularis Newstead (Homoptera: Diaspididae). Yearbook- South African - Mango Growers' Association, 16 : 20-22.

Longo, S.; Marotta, S.; Pellizzari, G.; Russo, A. and Tranfaglia, A. (1995) : An annotated list of the scale insects (Homoptera: Coccoidea) of Italy. Israel J. Entomol., 29: 113-130.

Morsi, G.A.; Girgis, M.F. and Abdel-Aziz, M. A. (2002): The Population Density of the Mango Scale, Aulacaspis Tubercularis (Newstead) (Homoptera: Diaspididae) and its Parasitoids in Middle Egypt. $2^{\text {nd }}$ International Conference, Plant Protection Research Institute, Cairo, Egypt, 21-24 December, 2002.

Moursi, K.S.; Gomaa, E.M. and Youssef , K.H. (1991): On the chemical control of the olive tree scale, Leucaspis riccae Targ. In dray farm system. J. Agric. Sci., Mansoura Univ., 16(4): 924-926.

Peña, J.E.; Mohyuddin, A.I. and Wysoki, M. (1997): The current mango pests management in the tropics and subtropics. Acta Horticulturae, 455: 812-820.

Porcelli F. (1990): New Italian scales. Frustula Entomologica, 13: 31-38.

Potenza M.R; Sato, M.E.; Raga, A.; De Souza Filho, M.F. (1993): Chemical control of Aulacaspis tubercularis Newstead (Hemiptera, Diaspididae) in mango orchards (Mangifera indica L.). Revista de Agricultura-Piracicaba, 68(3): 315-322.

Quednau, F. W. (1964): A contribution on the Genus Aphytis Howard in South Africa. (Hymenoptera: Aphelinidae) .J. Ent. Soc. Sth. Afr., 27 (1): 86-116.

Schoeman, A.S. (1987): First record of a parasitoid of the mango scale, Aulacaspis tubercularis (Newstead). J. Entomol. Soc. Southern Africa, 50: 259.

Snedecor, G.M. (1970): Statistical methods applied to experiments in Agriculture and Biology. Iowa State Press, U.S.A., 534 pp.

Stafford, E.M. and Summers, F.M. (1963): Evaluating control of San Jose scale. Univ. of California print, Hilgardia, 35: 13-32.

Tao, C. (1999): List of Coccoidea (Homoptera) of China. Taiwan Agricultural Research Institute, Wufeng, Taichung, Taiwan, China, 176 pp.

Van Halteren, P. (1970): Notes on the biology of the scale insect Aulacaspis mangiferae Newst. (Diaspididae : Hemiptera) on mango. Ghana J. Agric. Sci., 3: 83-85.

Viljoen, H.M and De Villiers, E.A. (1987): Effectiveness of fenvalerate and monocrotophos against the mango scale, Aulacaspis tubercularis Newstead. Information Bulletin, Citrus and Subtropical Fruit Research Institute, South Africa, No.173:19-23 
Viljoen, H. (1986): Natural enemies of mango scale. Information Bulletin. Citrus and Subtropical Fruit Research Institute, South Africa, 164: 8-9.

\section{ARABIC SUMMARY}

تقليل أعداد حشرة الماتجو القشرية البيضاء على أشجار الماتجو في محافظة البحيرة، مصر.

$$
\text { المعمل المركزى للمبيدات ـ مركز البحوث الزب شبر اعيةـ الصبحية ـاسكندرية }
$$

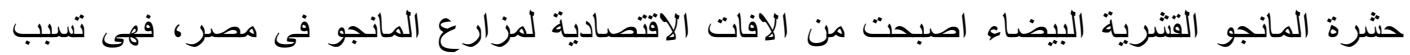

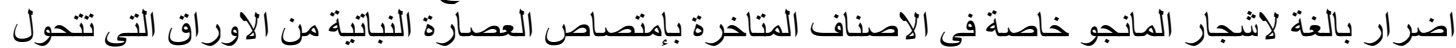

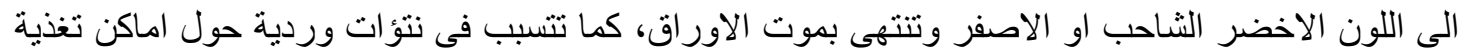

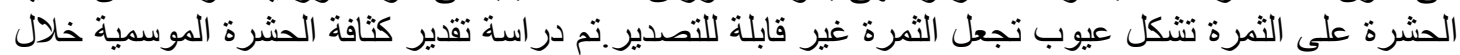

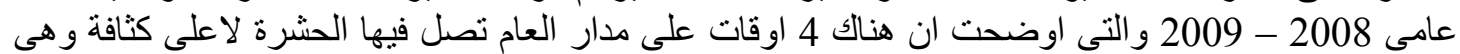

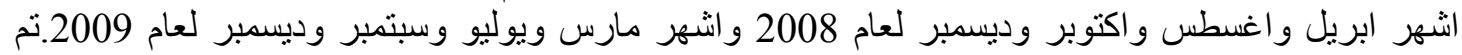

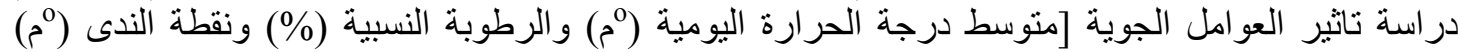

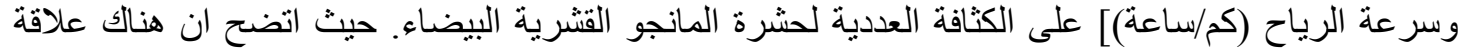

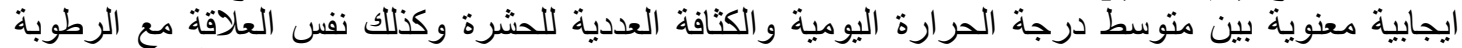

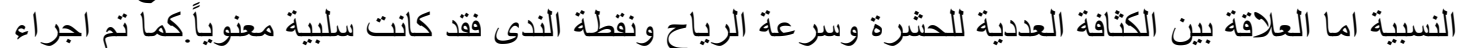

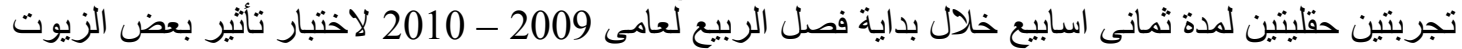

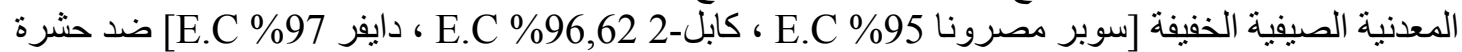

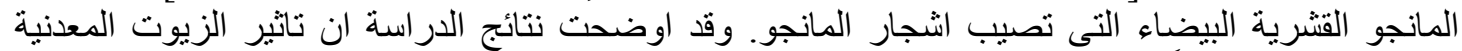

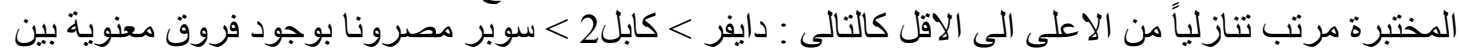

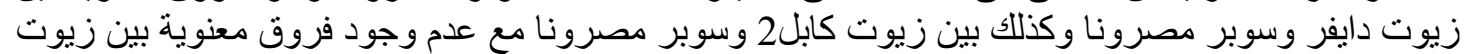

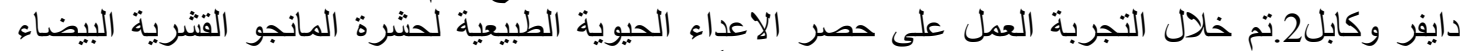

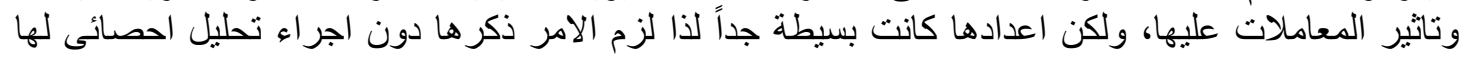

و هى متطفلة (Aphytis mytilaspidis, and Encarsia citrina) ومفترسة ونس (Chilocorus) bipustulatus and Scymnus syriacus) 